(2) Open Access Full Text Article

CASE REPORT

\title{
Bleeding from gastric body varices effectively treated with endoscopic band ligation
}

This article was published in the following Dove Press journal:

International Medical Case Reports Journal

18 October 2012

Number of times this article has been viewed

\section{Takahiro Sato \\ Sho Kitagawa}

Department of Gastroenterology, Sapporo Kosei General Hospital, Sapporo, Japan
Correspondence: Takahiro Sato Department of Gastroenterology, Sapporo Kosei General Hospital, Kita 3 Higashi 8, Chuo-ku,

Sapporo 060-0033, Japan

$\mathrm{Tel}+8 \mid$ | | 26| $533 \mid$

Fax +8I I| $26 \mid 6040$

Email taka.sato@ja-hokkaidoukouseiren. or.jp
Abstract: A 55-year-old man with alcoholic liver cirrhosis was admitted to hospital with tarry stools. Videoendoscopy examination on admission revealed blood oozing from the greater curvature of the gastric body (ectopic varices). Endoscopic ultrasonography and computed tomography were used in making the diagnosis. Endoscopic band ligation (EBL) was performed for the bleeding site of these varices. The patient experienced no further episodes of bleeding during the 6 months following treatment with EBL. EBL was very effective in treating the bleeding from gastric body varices.

Keywords: ectopic varices, endoscopic band ligation, gastric body varices, portal hypertension

\section{Introduction}

Gastric variceal bleeding is a common condition, and is associated with higher morbidity and mortality rates than hemorrhage from esophageal varices. ${ }^{1}$ Hemodynamic studies on gastric varices have been performed worldwide. Endoscopic ultrasonography (EUS) is considered very useful in the evaluation of gastric varices, ${ }^{2-4}$ whereas magnetic resonance and computed tomography (CT) allow assessment of the entire portal venous system. ${ }^{5,6}$

Here, we report on a rare case of variceal bleeding on the greater curvature of the gastric body (ectopic varices) in a liver cirrhotic patient.

\section{Case report}

A 55-year-old man with alcoholic liver cirrhosis was admitted to hospital with tarry stools. He had been diagnosed with liver cirrhosis at 36 years of age based on laboratory data and imaging studies and received endoscopic injection sclerotherapy to treat esophageal varices at 54 years of age. The patient had had several incidences of encephalopathy. On admission, he had anemic conjunctivae and scleral icterus. There were no abdominal masses. Laboratory findings were within normal ranges except for the red blood cell count, which was $302 \times 10^{4} / \mu \mathrm{L}^{3}$ (normal: $353-466 \times 10^{4} / \mu \mathrm{L}^{3}$ ), hemoglobin $8.8 \mathrm{~g} / \mathrm{dL}(10.6-14.4 \mathrm{~g} / \mathrm{dL})$, platelet count $4.2 \times 10^{4} / \mu \mathrm{L}^{3}\left(13.8-30.9 \times 10^{4} / \mu \mathrm{L}^{3}\right)$, total bilirubin $3.5 \mathrm{mg} / \mathrm{mL}(0.2-1.2 \mathrm{mg} / \mathrm{mL})$, and serum albumin $3.6 \mathrm{~g} / \mathrm{mL}(4.0-5.2 \mathrm{~g} / \mathrm{mL})$. The prothrombin time was 54\% (90\%-140\%). Videoendoscopic examination on admission revealed blood oozing from the greater curvature of the gastric body (Figure 1A). However, endoscopic finding is not sufficient to distinguish between gastric varices or the gastric fold. Esophageal varices were eradicated. 
EUS revealed the vessels in the mucosal and submucosal regions of the stomach (Figure 1B), and collateral veins around the greater curvature of the gastric body and splenomegaly were visualized by CT (Figure 1C). On CT, neither portal vein thrombosis nor splenic vein thrombosis was evident.

The diagnosis was gastric body variceal bleeding (ectopic varices) with EUS and CT findings. Endoscopic band ligation

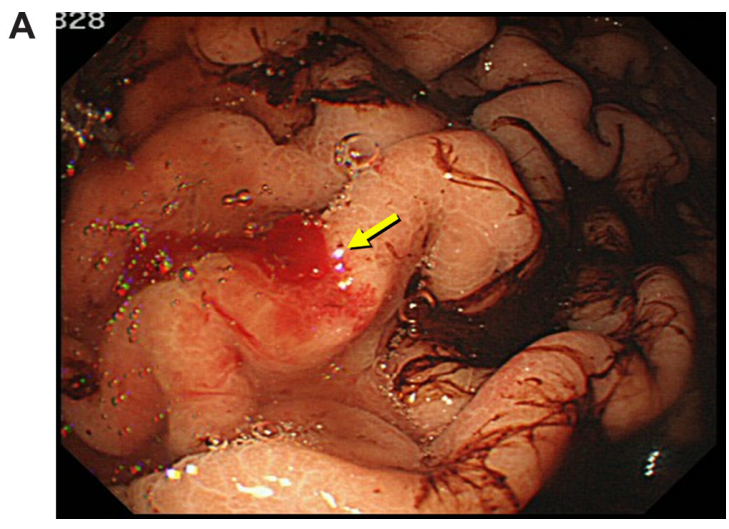

B

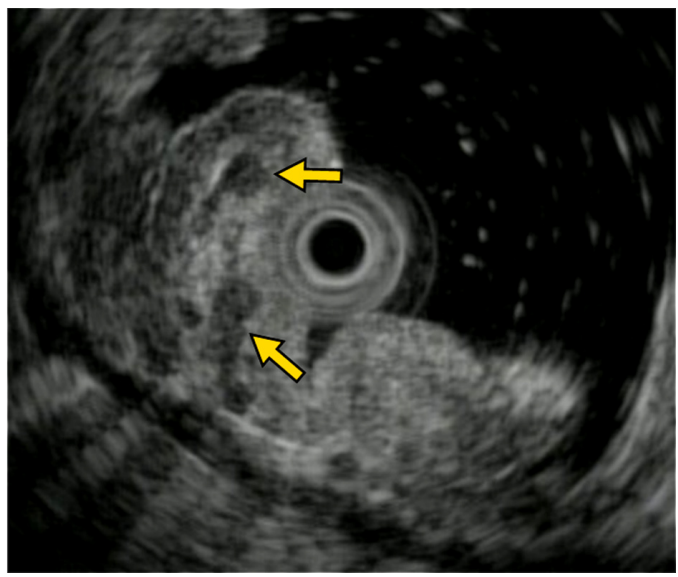

C

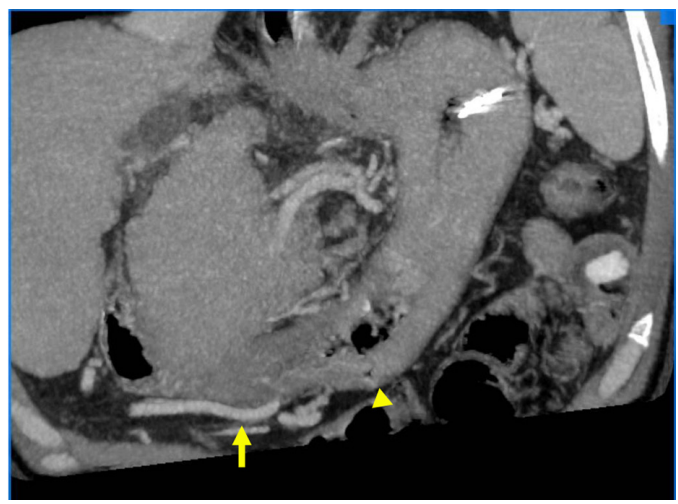

Figure I (A) Fibergastroscopic images revealing blood oozing from the curvatura ventriculi major of the gastric body (arrow). (B) Endoscopic ultrasonography revealing the vessels in the mucosal and submucosal regions of the stomach (arrows). (C) Collateral veins (arrow) around the curvatura ventriculi major of the gastric body (arrowhead) were visualized by computed tomography.
(EBL) was performed for the bleeding site of these varices (Figure 2A), and the site was effectively treated using only one rubber band. One week after EBL, endoscopy revealed an ulcer in the stomach (Figure 2B). The patient experienced no further episodes of bleeding during the 6 months following treatment with EBL.

\section{Discussion}

Endoscopy, a useful modality for diagnosing and observing gastric varices of a certain size and extent, has a very sensitive predictive value for variceal hemorrhage. ${ }^{7}$ In this case, videoendoscopic examination revealed blood oozing from the greater curvature of the gastric body. Esophagogastric varices are considered the most common complication in patients with portal hypertension, while ectopic varices (ie, those outside the esophagogastric region) are less common. Bleeding from ectopic varices, which is rare in patients with portal hypertension, is generally massive and life threatening. ${ }^{8,9}$ However, there are few reports on the clinicopathological features of ectopic varices. Ordinary gastric varices can be classified as either fundal, or cardiac and fundal (located between the cardiac orifice and the fundus). ${ }^{10}$ Therefore, this case may be defined as ectopic varices.

Splenic vein occlusion (characterized by gastric varices and splenomegaly with normal liver function) can result in sinistral portal hypertension ${ }^{11-13}$ that develops secondary to various diseases. Occlusion of the splenic vein results in venous flow draining into collateral veins, including the short gastric vein and left gastroepiploic veins. Increased blood flow in these vessels dilates submucosal veins of the stomach, causing gastric varices that often do not demonstrate clinical symptoms, but can result in hypersplenism or gastrointestinal hemorrhage. Gastric varices due to splenic vein occlusion show a round fundal region at the center, with varices that expanded to the greater curvature of the gastric body. ${ }^{12-14}$ However, neither portal vein thrombosis nor splenic vein thrombosis was evident on CT in this patient. We suspect that severe portal hypertension had induced variceal bleeding of the gastric body in this case.

In patients with poor condition, interventional radiologic treatment - such as insertion of a transjugular intrahepatic portosystemic shunt (TIPS) for ectopic varices - has been performed as a nonoperative treatment option. ${ }^{9}$ Although TIPS is a relatively safe and effective means of decompressing the portal pressure, we did not adopt TIPS because of severe liver atrophy and encephalopathy.

EBL is widely applied as an effective and standard treatment for esophageal varices because of obliteration of the submucosal varices. ${ }^{15}$ Further, EBL has been 

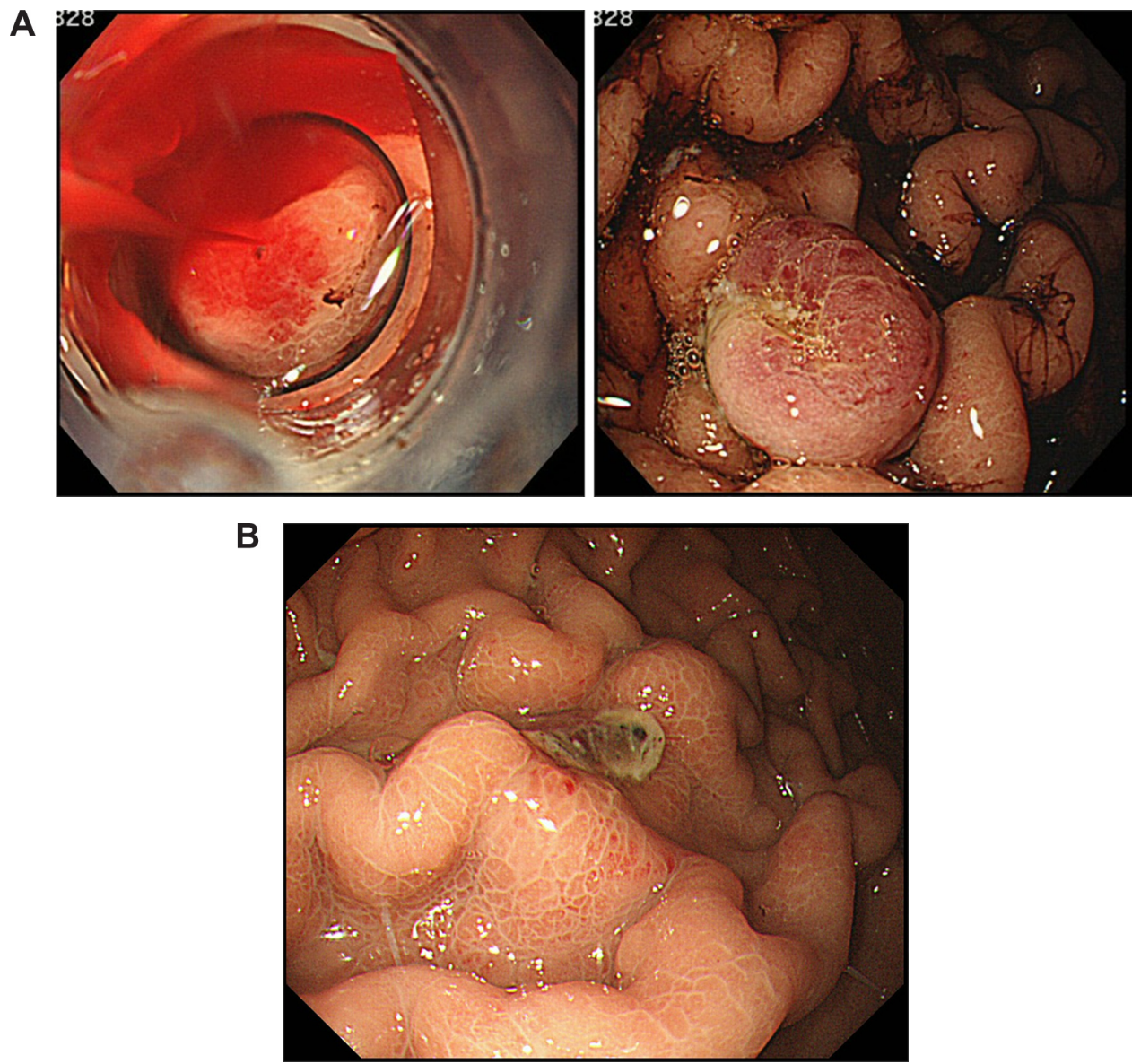

Figure 2 (A) Endoscopic band ligation performed for the bleeding site of these varices.

(B) One week after endoscopic band ligation, an ulcer in the stomach revealed by endoscopy.

performed as an effective procedure for other gastrointestinal diseases. ${ }^{16,17}$ In contrast, endoscopic injection sclerotherapy (EIS) is now a standard procedure for the treatment of esophageal varices. ${ }^{18}$ However, it is necessary to evaluate the hemodynamics of the gastric varices before EIS to avoid severe complications such as pulmonary embolism. EBL is reportedly both easier to perform and safer than EIS. In this emergency case, EBL was chosen as a nonoperative and effective treatment.

\section{Conclusion}

EBL was very useful for variceal bleeding of the gastric body in this liver cirrhotic patient. However, 6 months follow-up was not long enough and this point may be a limitation of this report.

\section{Disclosure}

The authors declare no conflicts of interest, financial or otherwise, in this work.

\section{References}

1. Trudeau W, Prindiville T. Endoscopic injection sclerosis in bleeding gastric varices. Gastrointest Endosc. 1986;32(4):264-268.

2. Boustière C, Dumas O, Jouffre C, et al. Endoscopic ultrasonography classification of gastric varices in patients with cirrhosis. Comparison with endoscopic findings. J Hepatol. 1993;19(2):268-272.

3. Caletti GC, Brocchi E, Ferrari A, Fiorino S, Barbara L. Value of endoscopic ultrasonography in the management of portal hypertension. Endoscopy. 1992;24 Suppl 1:342-346.

4. Sanyal AJ. The value of EUS in the management of portal hypertension. Gastrointest Endosc. 2000;52(4):575-577.

5. Cho KC, Patel YD, Wachsberg RH, Seeff J. Varices in portal hypertension: evaluation with CT. Radiographics. 1995;15:609-622.

6. Sato T, Yamazaki K, Toyota J, Karino Y, Ohmura T, Suga T. Evaluation of magnetic resonance angiography in detection of gastric varices. J Gastroenterol. 1999;34(3):321-326.

7. Hosking SW, Johnson AG. Gastric varices: a proposed classification leading to management. Br J Surg. 1988;75(3):195-196.

8. Kinkhabwala M, Mousavi A, Iyer S, Adamsons R. Bleeding ileal varicosity demonstrated by transhepatic portography. AJR Am J Roentgenol. 1977;129(3):514-516.

9. Norton ID, Andrews JC, Kamath PS. Management of ectopic varices Hepatology. 1988;28(4):1154-1158.

10. Idezuki Y. General rules for recording endoscopic findings of esophagogastric varices (1991). Japanese Society for Portal Hypertension. World J Surg. 1995;19(3):420-423. 
11. Sutton JP, Yarborough DY, Richards JT. Isolated splenic vein occlusion. Review of literature and report of an additional case. Arch Surg. 1970; 100(5):623-626.

12. Babb RR. Editorial: Splenic vein obstruction: a curable cause of variceal bleeding. Am J Dig Dis. 1976;21(6):512-513.

13. Muhletaler C, Gerlock AJ Jr, Goncharenko V, Avant GR, Flexner JM. Gastric varices secondary to splenic vein occlusion: radiographic diagnosis and clinical significance. Radiology. 1979;132(3):593-598.

14. Sato T, Yamazaki K, Akaike J, Toyota J, Karino Y, Ohmura T. Clinical and endoscopic features of gastric varices secondary to splenic vein occlusion. Hepatol Res. 2008;38(11):1076-1082.

15. Goff JS, Reveille RM, Stiegmann GV. Endoscopic sclerotherapy versus endoscopic variceal ligation: esophageal symptoms, complications, and motility. Am J Gastroenterol. 1988;83(11):1240-1244.
16. Berkelhammer C, Moosvi SB. Retroflexed endoscopic band ligation of bleeding internal hemorrhoids. Gastrointest Endosc. 2002;55(4): $532-537$.

17. Matsui S, Kamisako T, Kudo M, Inoue R. Endoscopic band ligation for control of nonvariceal upper GI hemorrhage: comparison with bipolar electrocoagulation. Gastrointest Endosc. 2002;55(2):214-218.

18. Sumino M, Toyonaga A, Tanikawa K. Evaluation of patient outcome following sclerotherapy for esophageal varices. J Gastroenterol. 1996; 31(3):387-393.

\section{Publish your work in this journal}

The International Medical Case Reports Journal is an international, peer-reviewed open-access journal publishing original case reports from all medical specialties. Previously unpublished medical posters are also accepted relating to any area of clinical or preclinical science. Submissions should not normally exceed 2,000 words or
4 published pages including figures, diagrams and references. The manuscript management system is completely online and includes a very quick and fair peer-review system, which is all easy to use. Visit http://www.dovepress.com/testimonials.php to read real quotes from published authors.

Submit your manuscript here: http://www.dovepress.com/international-medical-case-reports-journal-journal 